Joanna Getka

DOI $10.15290 / \mathrm{sw} .2016 .16 .30$

Uniwersytet Warszawski

Wydział Lingwistyki Stosowanej

Katedra Studiów Interkulturowych

Europy Środkowo-Wschodniej

tel.: +48225534229

e-mail: j.getka@uw.edu.pl

\title{
Świat chrześcijański wobec dziedzictwa słowiańskiego. Wyobrażenia ludowe w bazyliańskich Teologiach moralnych (XVIII wiek)
}

Słowa kluczowe: bazylianie, drukarstwo ruskojęzyczne, teologie moralne, zabobony, XVIII wiek

\section{Wstęp}

Ze względu na nurtujące człowieka od zarania dziejów problemy egzystencji ludzkiej, kultury budowano na podłożu religijnym. Dzięki współistnieniu kultury i religii wytwarzał się kanon zachowań, pojęć i wierzeń typowych dla danej grupy. Wraz z pojawieniem się nowych systemów religijnych na danym terenie i prowadzonej akcji misyjnej następowało przenikanie się i konfrontowanie nowych wierzeń z zastanym systemem wartości. Ten proces asymilacji kulturowej nowych wartości jest naturalny, co można zaobserwować w obrzędach lokalnych wybranych nurtów religijnych. Dziś jest to dobrze widoczne m.in. na Podlasiu i Polesiu: „Białorusini, to jeden z niewielu narodów, które zdołały pogodzić poszanowanie chrześcijaństwa z wiarą w siłę w swej istocie pogańskich obrzędów" [Voronau 2014, 7]. Hierarchowie kościelni, co oczywiste, dążyli do wykrzewienia tego typu obrzędów, a wobec niemożliwości dokonania tego - do adaptacji praktyk bądź wierzeń na potrzeby własnych dogmatów. 
W efekcie w świadomości ludowej wytworzyła się własna religijność, stanowiąca swoistą kontaminacje prawdy objawionej z wierzeniami ludowymi. Wzajemne przenikanie się tradycyjnej religijności ludowej z religijnością w rozumieniu nauki Kościoła było szczególnie silne w Kościele greckokatolickim, którego wierni reprezentowali ludność chłopską.

Opracowane z myślą o nauczaniu tej ludności XVIII-wieczne ruskojęzyczne teologie moralne (etyki chrześcijańskie) zawierające nauczanie Kościoła dotyczące norm postępowania, były pod silnym wpływem ludowych wierzeń i wyobrażeń. Stosowane w tych książkach schematy interpretacyjne wyraźnie się do nich odwoływały. Zaznacza się w nich problematyka asymilacji wątków kultury chrześcijańskiej z jednej strony, z drugiej zaś przewartościowanie wierzeń lokalnych.

Celem artykułu jest charakterystyka stanu wierzeń ludowych, myślenia magicznego na ziemiach wschodnich dawnej Rzeczypospolitej w XVIII wieku na tle dogmatów ówczesnej greckokatolickiej teologii moralnej. Wraz z rozwojem nauki i wzrostem wykształcenia oba te systemy uległy modyfikacjom, nadal jednak wzajemnie się przenikają, zwłaszcza w kulturze ludowej.

\section{Ruskojęzyczne teologie moralne ${ }^{1}$}

Geneza ruskojęzycznych teologii moralnych leży w postanowieniach Synodu Zamojskiego, dokładnie zaś decyzji, które zapadły na trzeciej i ostatniej sesji publicznej Synodu, która odbyła się 17 września 1720 roku w kościele Opieki Najświętszej Maryi Panny w Zamościu. Dotyczyły one reformy życia kościelnego i religijnego Cerkwi greckokatolickiej. Choć różne są opinie co do roli politycznej, religijnej czy kulturowej samego Synodu [Melnyk net, Чистович 1884, 378-382, Зноско 1932], to w kontekście podjętej analizy ważny jest podkreślony tam problem konieczności intensywnej pracy nad poprawą poziomu świadomości religijnej ludu. Z dokuczliwym brakiem znajomości fundamentalnych prawd wiary wśród ludu postanowiono walczyć poprzez wprowadzenie obowiązku nauczania wiernych po niedzielnej mszy i w innych okolicznościach (misje, święta itp.). Za niewykonywanie go duchowieństwu groziła nie tylko kara finansowa, ale również zawieszenie w urzędzie (co również łączyło się z utratą zysków z beneficjum). Sprawa

1 Badania prowadzone dla potrzeb niniejszej analizy zostały sfinansowane ze środków Narodowego Centrum Nauki przyznanych na podstawie decyzji numer DEC-2012/07/D/ HS2/03672. 
nie była jednak prosta - sami parochowie mieli problemy z poprawną interpretacją zasad wiary, przy jednoczesnym braku możliwości zdobycia tej wiedzy ze względu na brak opracowań w języku, którym się posługiwali. W XVIII wieku językiem komunikacji wiernych kościoła unickiego, a także prostych parochów był język „prosty”, „ruski”. Ze względu na brak gramatyk tego języka, można go opisywać na podstawie zachowanych tekstów, i w największym uproszczeniu scharakteryzować jako język mieszany z przewagą elementów językowych białoruskich na północy tego obszaru i cech ukraińskich - na południu [Getka 2012, 27-35]. Znajomość języka cerkiewnosłowiańskiego, mimo opanowania cyrylicy, była słaba, teksty w języku polskim - ze względu na alfabet wcale nie były bardziej przystępne ${ }^{2}$.

Dla upowszechnienia zebranych w jednym opracowaniu dogmatów Synod zobowiązał się przygotować katechizm w języku ruskim, który miał być pomocny parochom w prowadzeniu misji. Efektem postanowień Synodu jest wydany w 1722 roku w Supraślu tekst teologii moralnej o charakterze katechizmowych pytań i odpowiedzi: Собранїе прыпадковъ краткое и дух[о]вньмъ особамъ потребное импщее въ себп науку о сакраментахъ, о десати Б[ж]їихъ приказаняхъ о приказаняхъ иерковньхъ и о науии хрїстїанской съ вьюладомъ молитвы Отче нашъ и B[o](г)[о]родыце Дюво ильи исповпданьия Вирп православнія католичискїя... (dalej: Собранїе припадковъ...).

Książka ta jest wzorowana na polskojęzycznych wydaniach tego typu, np. Teologia, Teologia moralna czy Teologia dogmatyczna [Narolski 1777; Narolski 1791; Koronczewski 1779; Kyriatt 1799; Kulczycki 1787; Kulczycki 1792] (również wydawanych m.in. przez bazylianów), które zawierały standardowo traktaty o przykazaniach boskich i kościelnych, o sakramentach (chrztu, bierzmowania, eucharystii, pokuty, ostatniego namaszczenia, kapłaństwa, małżeństwa), grzechach. Traktaty te miały schematyczną strukturę - zaczynały się od ogólnej charakterystyki zagadnienia, a następnie tłumaczyły je szczegółowo w formie katechizmowych pytań i odpowiedzi.

\footnotetext{
2 Konieczność tłumaczenia na prosty język modlitw widziano już wcześniej, ale również w ciągu całego XVIII wieku. Nawet cerkiewnosłowiańskie modlitwy sugerowano czytać lub tłumaczyć po rusku (Por. np. [Слово къ народу кафоліческому 1765, 80-81], [Trebnik 1741, 158]; było to zresztą powtórzenie tez zawartych w Trebniku Piotra Mohyły [Mohyła 1646, 55]. W założeniu nie miało to zresztą stanowić konkurencji dla cerkiewszczyzny, który miał pozostawać językiem liturgii. Jest to zarazem odpowiedź na pytanie o przyczyny druku książek o charakterze dydaktycznym moralizatorsko-nauczającym pisanych простим язиком простійшаго ради іже по всех народа... [СЪ̈мя слова Божія 1772], [СЪмя слова Божія 1781]. Bazylianie wydali po rusku kilka tego typu tekstów, każdy z nich był kilkukrotnie przedrukowany. Najbardziej potrzebną i popularną okazało się Teologia Moralna, w zależności od czasu i miejsca wydania miała różne tytuły.
} 
Tekst ruskojęzyczny był pozbawiony tej wstępnej charakterystyki zagadnienia, wszystkie poruszane problemy zawierały się w odpowiedziach na kolejne pytania związane z tematem.

Z dzisiejszej perspektywy widać, że Собранїе припадковъ..., którego treść modyfikowano i redagowano usuwając niektóre fragmenty i dodając inne - było jedną z najważniejszych unickich wykładni zarówno spraw dogmatycznych, jak i etycznej edukacji wiernych. W ciaggu XVIII wieku tylko spod pras drukarni bazyliańskich w Supraślu, Uniowie i Poczajowie pod różnymi tytułami (Краткое сословіе науки хрістіанскія..., Поученіе о с[вя]тих тайнах..., Богословіа нравоучителная... ${ }^{3}$ ) wyszło co пајmniej siedem wydań tego dzieła. Książkę wydano również w innych drukarniach, np. we lwowskiej drukarni bractwa przy katedrze Zaśnięcia Najświętszej Marii Panny w 1752 [Богословіа нравоучителная 1752].

Poza tym, w Poczajowie ukazały się kilkakrotnie teksty o tytule, zbliżonym do wydanych tam wersji Собранїя припадковъ... (Богословіе нравоучителное повсемственное [Антоіне 1776]; [Антоіне 1776]; [Антоіне 1779]; [Краткое на краткія вопрось и отвпты способом катихісма Богословія 1788]; [Богословіе нравоучителное 1793]), ale nie będą one przedmiotem niniejszego tekstu ze względu na język: są to teksty cerkiewnosłowiańskie. Ponadto ich treść odbiega od prezentowanych wyżej kolejnych wydań Teologii moralnej.

Wzmiankowane wydania teologii moralnej były w założeniu kierowane do duchownych unickich oraz osób sposobiących się do stanu kapłańskiego.

Warto wspomnieć, że o ile pierwsze wydanie teologii Собранїе припадковъ... składa się z piętnastu rozdziałów, to kolejne edycje - mimo bardzo podobnej treści, mają inną budowę. Zostały one podzielone na IV części: z których I odpowiada rozdziałom 1-11 Sobranija..., II część stanowi rozdział 12. wydania z 1722 roku, III - rozdziały 13. i 14. wydania z Supraśla, a IV - rozdział 15. Mimo różnicy w budowie, zawartość tekstów niewiele się różni.

W efekcie ruskojęzyczne etyki chrześcijańskie są z jednej strony świetnym źródłem do analizy stanu obrządku unickiego w okresie po Soborze Zamojskim, z drugiej zaś - ze względu na fakt, że dotyczyły nie tylko administracji kościoła, ale również obowiązków kapłanów, zarówno w zakresie

3 Bibliografie i katalogi biblioteczne pozwalają wymienić dziś dwa wydania supraskie z 1722 roku [Собранїе прыпадковъ 1722] i skróconą jego wersję z 1759, stanowiące końcową część Собранїя..., zawierającą wykład wiary katolickiej, kredo, podstawowe modlitwy [Краткое сословіе 1759]; dwa wydania uniowskie [Собраніе припадков 1732]; [Поученіе о с[вя]тих тайнах 1745] i trzy poczajowskie [Богословіа нравоучителная 1751]; Богословіа нравоучителная 1756]; [Богословия нравоучителная 1787]. 
odprawiania i przystępowania do sakramentów, jak i życia osobistego - są znakomitym materiałem do poznania systemu wartości i wyobrażeń ludzi związanych z kręgiem kultury unickiej.

Teksty te, odzwierciedlają również wierzenia i ludowe obrzędy dawnych wschodnich ziem Rzeczypospolitej. Nie są one oczywiście opisane wprost, ale różnego rodzaju zakazy, czy też lista potencjalnych grzechów daje o nich znakomite wyobrażenie.

Właśnie te elementy życia duchowego ludności związanej z kręgiem kultury unickiej: (przesądy i zabobony, wróżbiarstwo, myślenie magiczne) będą przedmiotem niniejszego artykułu.

\section{Tradycje słowiańskie w bazyliańskich teologiach moralnych}

Choć chrystianizacja Słowian rozpoczęła się w IX w. (chrzest Wielkich Moraw i akcja misyjna Konstantego-Cyryla i Metodego), to ludność słowiańska długo była wierna swoim dotychczasowym wierzeniom, a pozostałości dawnych obrządków występują w folklorze również obecnie. Szczególnie silne wpływy dawnych wierzeń panowały na wschodnich ziemiach dawnej Rzeczypospolitej. O wyjątkowym miejscu tych ziem w demonologii ludowej czy wierze w siły nadprzyrodzone świadczą dodatkowo fakty lingwistyczne: już sama nazwa 'upiór' pochodzi od ruskiego 'upyr'. Oczywiście w XVIII wie$\mathrm{ku}$ funkcjonowała ona równolegle $\mathrm{z}$ nazwami: upirzyca, upierzyca, strzyga, czy (z bułg. z nosówką) wampierz [Brückner 1970, 594]. Co więcej, ludowe wyobrażenia o nierozerwalnym połączeniu zjawisk świata naturalnego i sił nadprzyrodzonych przejawiających się $\mathrm{w}$ wierze $\mathrm{w}$ działanie czarów, magii orazistnienie demonów zachowały się do dziś, co ma wyraz w popularności usług szeptuch i uzdrowicieli na Podlasiu [Voronau 2014].

Zachowanie tego typu wyobrażeń można częściowo tłumaczyć geografia tych ziem - pokrytych puszczami, w których osady i wsie były odcięte od wielkich skupisk ludzkich. Powodowało to nie tylko ograniczoną wymianę handlową czy dostęp do edukacji (też nauki Kościoła), ale przede wszystkim mniejszą możliwość uzyskania pomocy lekarskiej w razie choroby ludzi czy zwierząt domowych. Niezrozumienie wielu zjawisk prowadziło do pojawienia w świadomości ludzi wyobrażenia o ich nadprzyrodzonych przyczynach. W efekcie winę za choroby, śmierć, wszelkie niepowodzenia, które dotykały człowieka, a także najróżniejsze klęski żywiołowe przypisywano złej woli duchów i ludzi spowodowanej za pomocą czarów [Gloger 1900, 266]. W związku z tym w nieoczekiwanych przypadkach lub w chorobie, kiedy nie pomogły znane środki naturalne (zioła, leki pochodzenia roślinnego) udawano się do 
osób, które - jak wierzono - dzięki zdobyciu wiedzy tajemnej, bądź tė̇ posiadaniu mocy czarodziejskiej - potrafiły poradzić w krytycznych sytuacjach. Udawano się do nich równie chętnie, by uchronić się przed działaniem złych ludzi, a także zaszkodzić bądź pomóc jakiejś osobie. Z drugiej strony - na takie osoby równie chętnie zrzucano również winę za zjawiska, których nie potrafiono wyjaśnić (nagła choroba, brak mleka u krów czy nieniesienie się kur).

Jest oczywiste, że Kościół dążył do wykrzewienia tego typu wierzeń nauczając, że są to działania inspirowane przez diabła, a ludzie się nimi zajmujący są bądź przez niego opętani, bądź też są jego współpracownikami [Baranowski 1965, 157-158]. Uniwersalnym antidotum miała być chrześcijańska „nadzieja w Bogu, w chrzcie, w spowiedzi, komunii, spowiedzi, eucharystii, modlitwie, postach, wodzie święconej, krzyżu, relikwiach świętych, pomocy Maryi, Aniołów i wszystkich świętych" 4 [Собранїе прыпадковъ 1722, $105 \mathrm{~L}-106 \mathrm{P}]$; [Поученіе о с[вя]тих тайнах 1745, 106P-107P]; [Богословіа нравоучителная 1756, 96P-98L]. Takie podejście ma odzwierciedlenie w wydawanych przez bazylianów teologiach moralnych - piętnują one wszelkie przejawy wiary w siły nadprzyrodzone.

Szeroką wykładnię omawianej problematyki przynosi zwłaszcza analiza grzechów przeciw pierwszemu przykazaniu, wśród których piętnowane są magia, wróżbiarstwo czy medycyna okultystyczna. Z tymi elementami łączą się nierozerwalnie zabobony i wiara w przesądy i wróżby, a także moce nadprzyrodzone niektórych osób, które pochodzić miałyby od diabła.

Zabobony rozpatrywane sa w tym samym kontekście co bałwochwalstwo, a słowa te uznawane są za synonimiczne: oddawanie się czarom i wiara w zabobony to oddawanie czci nie Bogu, ale Bałwanom: Słońcu, Gwiazdom i Księżycowi i in. W efekcie - wszystkie wymienione „niemiłe Bogu” czynności typu: czary, gusła, „charaktery noszenia”, zapisywanie się diabłom (paktowanie z diabłem), udawanie się do bab-czarownic, kuszenie, na strzelbie przysięganie, zamowy, wieszczby, wróżby, wiara w sny i inne są zarazem znakomitym materiałem kulturoznawczym, dotyczącym praktyk ludowych w XVIII wieku [Собранїе прыппажовъ 1722, 105L-106P], [Поученіе о с[вя]тих тайнах 1745, 106P-107P], [Богословіа нравоучителная 1756, 96P-98L].

Tłumaczono też, że wiara w przepowiednie na podstawie zjawisk przyrody lub zachowania zwierząt (tak zwane doświadczenie niepotrzebne) również

4 Tu i niżej, wszystkie teksty zaczerpnięte $\mathrm{z}$ teologii moralnych podaję we własnym tłumaczeniu - Joanna Getka. 
jest grzechem śmiertelnym. Takim zbędnym - „niepotrzebnym” doświadczeniem było na przykład doświadczenie szczęścia/nieszczęścia ze znaków zwierzęcych (na przykład: nieszczęścia po spotkaniu na drodze zająca). Na równi z nim podawano inne przykłady: wiarę, że cel można osiągnąć bez pracy i nauki, tylko przez modlitwę (co z kolei wpisywało się przy okazji w oświeceniową działalność bazylianów) [Собранїе прыпадковъ 1722, 105L-106P], [Поученіе о с [вя]тих тайнах 1745, 106P-107P], [Богословіа нравоучителная 1756, 96P-98L].

Wróżbiarstwo - podkreślano - to „prorokowanie niepewne”, dane od diabła wróżbicie, o rzeczach przyszłych albo współczesnych - nieznanych, których sam Szatan pochodzi ze Słońca, Gwiazd, Księżyca, elementów doświadczenia i naszych predyspozycji. Takie wróżbiarstwo jest dwojakie: kiedy ktoś używa sposobów, do jakich dostęp może mieć sam diabeł (pałeczką np. wróżby mające na celu odkrycie jakiegoś skarbu, albo skradzionej rzeczy), drugie: kiedy ktoś wyraźnie „zapisuje się szatanowi” (oddaje szatanowi duszę), albo z powietrza ulepi sobie ciało, albo pojawi się w ciele jakiejś opętanej osoby [Собранїе прыпадковъ 1722, 105L-106P], [Поученіе о с[вя]тих тайнах 1745, 106P-107P], [Богословіа нравоучителная $1756,96 \mathrm{P}-98 \mathrm{~L}]$.

Problematyka czarów i czarowników wraca wielokrotnie w tekstach przy okazji omawiania różnych kwestii moralno-teologicznych. Co ciekawe, pojawia się często w - na pierwszy rzut okiem - zaskakujących momentach (przy omawianiu sakramentu chrztu, małżeństwa, odprawiania mszy itd.). Analizowany jest np. problem chrztu dziecka ciężarnej skazanej na śmierć za czary. Warto wspomnieć, że dopiero w 1776 roku uchwalono w Polsce „Konwikcyje w sprawach kryminalnych" (Vol. leg. VIII, f. 882), które zakazywały zarówno stosowania tortur (we wszystkich sprawach kryminalnych), jak i stosowania kary śmierci wobec osób oskarżonych o czary [Gloger 1900, 275]. W omawianych tekstach sugerowano odroczenie wykonania wyroku do czasu porodu. Dziecko miało być ochrzczone [Собранїе прыпадковъ 1722, 12L], [Богословіа нравоучителная 1756, 9P], [Поученіе о с[вя]тих тайнах 1745, 10L].

Dążenie do usunięcia czarowników i czarownic ze społeczeństwa pojawia się również przy omawianiu kwestii dziedziczenia. Podejrzenia o kontakty z czarownikami mogły być bowiem - w myśl zapisów teologii moralnych - podstawa wydziedziczenia dzieci [Собранїе прыпадковъ 1722, 111L], [Поученіе о с[вя]тих тайнах 1745, 110P], [Богословіа нравоучителная $1756,102 \mathrm{~L}]$.

Przytoczone przykłady świadczą o ciekawym przenikaniu się tradycji ludowej z ustawodawstwem kościelnym i świeckim. Interesujące w tym kontekście wydaje się pytanie, czy prawo (np prawo dziedziczenia) odzwiercie- 
dlające wierzenia ludowe nie stwarzało pola do nadużyć w samej praktyce jego stosowania. Szukanie odpowiedzi na to pytanie nie jest jednak celem niniejszego artykułu.

Warto przy okazji wspomnieć o podobnym w skutki kazusie: przy charakterystyce sakramentu małżeństwa odnotowano, że jedną z przyczyn, dla których można odwołać obowiązkowe zapowiedzi przedślubne jest obawa, że na któregoś z narzeczonych może zostać rzucony czar [Собранїе nрыпадковъ 1722, 79P], [Поученіе о с[вя]тих тайнах 1745, 85L], [Богословіа нравоучителная $1756,67 \mathrm{~L}]$. Jest oczywiste, że poza realnym strachem przed magią, taki zapis umożliwiał zerwanie zaręczyn z kandydatem niemile widzianym $\mathrm{w}$ rodzinie, a pretekstem mogło być trudne do ustalenia i zdiagnozowania opętanie.

Powszechną wiarę w czary odnajdujemy również podczas analizy pytań i odpowiedzi dotyczących sakramentu spowiedzi. Książki podają bowiem pytania pomocnicze, wśród których pojawiają się pytania o „oddawanie się czarom".

Czarom zresztą można było się nie tylko oddawać - praktykować, powszechną była wiara w możliwość rzucenia na kogoś czaru - uroku. Rzucenie uroku traktowane na równi z grzechem śmiertelnym mogło być np. - według wykładni autorów poradników - przyczyną nieuleczalnej impotencji [Coбранїе прыпадковъ 1722, 83P], [Поученіе о с [вя]тих тайнах 1745, 82P], [Богословіа нравоучителная 1756, 74P].

Rzucanie uroków kwalifikowane jako grzech przeciw pierwszemu przykazaniu potwierdza zarazem funkcjonującą w XVIII wieku wiarę w moc czarowników, którą otrzymują z woli szatana. W efekcie są zdolni nie tylko poznać materię rzeczy tajemnych, ale i zesłać na ludzi choroby, zły los, albo przeciwnie: wrócić zdrowie chorym [Собранїе прыпадковъ 1722, 105L-106P], [Поученіе о с[вя]тих тайнах 1745, 106P-107P], [Богословіа нравоучителная $1756,96 \mathrm{P}-98 \mathrm{~L}]$.

Wraz z upowszechnianiem się nauki Kościoła następowało teologicznego podejścia do wierzeń ludowych. Unaoczniają to fragmenty dotyczące pokuty zmarłych, która w ludowych wyobrażeniach była współmierna do winy popełnionej za życia. Pierwsze wydanie Sobranija zawiera mnóstwo dydaktycznych przypowieści nawiązujących do tych wierzeń i wyobrażeń. O ile autorzy tego pierwszego wydania z 1722 roku uznano, że obrazowe historie będą lepiej trafiały do niewykształconego ludu niż abstrakcyjny i niezrozumiały dla nich język teologów i często odwoływali się do baśniowych opowieści, to redaktorzy późniejszych wydań skrupulatnie usunęli tego typu przykłady jako zapewne niekanoniczne i gruntujące utrzymywanie się wierzeń ludowych. 
Zamieszczane przypowieści uczyły m.in. konieczności uczciwej i szczerej spowiedzi, zgodnie z przesłaniem, że Bóg widzi nasze serca i nic się przed nim nie da zataić. Podawano przy tym przykład okrutnej kary jaki otrzymała pewna kobieta, która zgrzeszywszy z krewnym, wstydziła się tego wyznać. Kiedy w końcu zdecydowała się wyspowiadać, zamiast słów leciały jej z buzi żaby, a nawet smok. Ponieważ najcięższego grzechu wstydziła się wypowiedzieć, ziejący ogniem smok, który już prawie opuścił jej ciało, wrócił do jej serca, a kobieta niedługo potem zmarła. Kiedy spowiadający ją jereje poprosili Boga o wyjawienie sekretu śmierci, ujrzeli kobietę jadącą na smoku, dwa psy gryzły jej ręce, dwie żmije uwiesiwszy się na jej szyi ssały jej piersi, dwie strzały przebiły jej uszy, na oczach miała żaby, a jaszczurka gryzła jej głowę. Kobieta wytłumaczyła im co to znaczy: jaszczurka gryzie ją za niegodne ubranie, żaby w oczach - za złe spojrzenia na ludzi, strzały ogniste za pieśni i słowa nieczyste, żmije za to, że dała się dotykać nieuczciwie i niecnotę, za brak pomocy biednym jedzie na smoku ognistym, który pali ją ciągłym ogniem (SP.1722:42P). Historia zakończona jest morałem - jereje otrzymali prostą odpowiedź na pytanie jak uniknąć piekła: owa potępiona powiedziała im, że kobiety dostają się tam najczęściej za rozwiązłość i zatajenie grzechów na spowiedzi oraz z powodu czarów. Podane dwie kluczowe przyczyny mogą znów wskazywać na dwa podstawowe kierunki działalności misyjno-wychowawczej bazylianów: moralność i kształtowanie postaw moralnych.

Podobne przemawiające do wyobraźni słuchaczy opowieści podawane są przy charakterystyce innych sakramentów. Liście grzechów przeciw sakramentowi Eucharystii w Sobraniju pripadkov... 1722 towarzyszą np. plastycznie przedstawione przykłady kar. Powołano się więc między innymi na los kobiety, która za czasów Cypriana poważyła się mimo grzechu przyjąć sakrament Eucharystii i została opętana przez szatana: najpierw odgryzła sobie język, potem zaś zmarła w mękach. Inny przykład mówi o mężczyźnie z pewnego miasta (podana jest nazwa: Дуляка, być może chodzi o Lukę, wł. Comune di Lucca - j.g.), który również przyjął sakrament bez spowiedzi i doznał ataku strasznych boleści, które utrzymywały się dopóki nie wypluł ciała Chrystusa do rynsztoku (bo jak podkreśla autor - Chrystus wolał być w rynsztoku niż u nieczystego człowieka [Собранїе прыпадковъ 1732, 24L]). Gdy ponownie ten sam człowiek przyjął eucharystię w grzechu pojawiły się „nieziemskie” muchy, które dotąd mu zadawały ból w ustach, dopóki się nie wyspowiadał. Podobnej kary doznał inny młodzieniec w Lucernie, który ze wstydu nie wyspowiadał się ze wszystkich swoich grzechów. Po połknięciu ciała Chrystusa poczuł, że zamieniło się ono w kamień i pewno by umarł, gdyby nie wyspowiadał się [Собранїе прыпадковъ 1722, 23L-P]. 
Myślenie magiczne przejawia się także $\mathrm{w}$ dydaktycznych przypowieściach o zachowaniu się po przyjęciu sakramentu, któremu winna towarzyszyć refleksja na temat ofiary z ciała i krwi Chrystusa. Wskazywano, że po przyjęciu sakramentu nie należy zwłaszcza udawać się do karczmy, bo człowiek, który oddaje się przez pijaństwo szatanowi, obraża Boga. Naukę tę także zilustrowano przypowieściami: tak zdarzyło się w Rzymie, kiedy ludzie przyjęli komunię, a następnie oddali się pijaństwu. Spotkała ich okrutna kara: krew śmierdząca leciała im z żył i umierali w mękach, deszcz obfity spadł na ziemię i zgniło zboże, a na drogach do miasta czatowały okrutne smoki, które rozrywały ludzi na strzępki. Trwało to do czasu, aż jakiś (bliżej nieokreślony) święty nie zaczął modlić się za klęski i wówczas ukazał mu się Anioł, który zapytał - Co trzeba zrobić z kimś, kto by syna królewskiego osadził niewinnie w ciemnicy? Według autora wydania: to samo zrobili z ciałem Chrystusa ci, którzy przyjęli go do ciemnicy swojego serca ludzie, którzy po komunii nie zachowują się jak należy. Ludzie zrozumieli grzech, poprosili o przebaczenie i wszystkie kataklizmy ustąpiły. Podobnie było w Rzymie za czasów Grzegorza Dialoga (Grigorij Dwojesłow). Miasto dotknęło morowe powietrze i trwało dopóty, dopóki ludzie, którzy po komunii oddali się pijaństwu, nie poprosili o przebaczenie. Również ta przypowieść zawiera przestrogę, jak straszna może spotkać człowieka kara, kiedy po komunii oddadzą się rozpustom, tańcom, pijaństwu i innym grzesznym uciechom [Собранїе прыпадковъ 1722, 24L-P, Собранїе прыпадковъ 1732, 25L-P].

Przytoczone wyżej przykłady, uwiarygodnione konkretnymi miejscami wydarzeń czy nazwiskami znanych osób, świadczą o głębokim przenikaniu się wierzeń cerkiewnych i wierzeń ludowych - wierze w diabła, i karze, spotykającej człowieka za życia i po śmierci, która jest współmierna do winy. Przykłady losu postępujących niezgodnie z etyką chrześcijańską miały skłonić do refleksji i poprawy wiernych. Należy jednak zauważyć, że w kolejnych wydaniach, od edycji z 1745 roku poczynając, przytoczone obrazowe fragmenty usunięto. Może to świadczyć o chęci wykrzewienia magicznego myślenia u chrześcijan z jednej strony, z drugiej zaś - o ewolucji świadomości religijnej.

\section{Zakończenie}

Bazyliańskie teologie moralne dostarczają wielu przykładów świadczących o przenikaniu się starych i nowych wierzeń i wyobrażeń z tradycją ukształtowaną w kulturze chrześcijańskiej. Czary, magia i czarnoksiężnicy, czarodzieje byli od zawsze obiektem zainteresowania zarówno społeczności 
świeckiej, jak i hierarchii kościelnej, która widziała w nich zagrożenie dla gruntowania wiary. Choć od samego początku chrystianizacji Kościół walczył nie tylko z zabobonami, ale i osobami z nimi kojarzonymi - zarówno oni i samo zjawisko przetrwało w świadomości ludzi ze względu na możliwość wytłumaczenia sobie zjawisk, których ludzie nie byli w stanie ogarnąć rozumem.

W efekcie, zalecane normy postępowania etycznego w tym zwłaszcza schematy interpretacyjne wyraźnie się do pogańskiego dziedzictwa odwoływały. Choć propagowanie wiary chrześcijańskiej przez używanie symboli i wyobrażeń stanowi ewidentny paradoks, to był to widać najlepszy wówczas środek do osiągnięcia oczekiwanych celów misyjnych. Wiek XVIII to jednak przede wszystkim wiek Oświecenia, wiek wykorzeniania zabobonów, ciemnoty i zacofania. Zaowocowało to ewolucją podejścia bazylianów do dziedzictwa ludowego - teolodzy starali się odchodzić od dydaktycznych przypowiastek odwołujących się do myślenia magicznego. Proces ten można zaobserwować w kolejnych wydaniach omawianych etyk chrześcijańskich: $\mathrm{w}$ wydaniach z 2 poł. XVIII wieku tego typu elementy zostały usunięte.

W końcu XVIII wieku, choć zaprzestano radykalnej walki z czarownicami (już nie palono ich na stosie) to w dalszym ciągu piętnowano wiarę w ich moc. Niezależnie od tego wróżbiarze byli na tyle silnie zakorzenieni w kulturze XVIII-wiecznych wschodnich prowincji dawnej Rzeczpospolitej, że przy wymienianiu różnego rodzaju „zawodów”, którym nie należy się opłata za świadczone usługi - wymieniani są właśnie czarodzieje [Собранїe прыпадковъ 1722, 115L], [Поученіе о с[вя]тих тайнах 1745, 118P], [Богословіа нравоучителная 1756, 108L]. Echo myślenia magicznego - jako element wierzeń ludowych pobrzmiewa jednak w wierzeniach religijnych do dziśs.

XVIII-wieczna etyka bazyliańska ulegała lokalnym wpływom, ubogacając teologiczne interpretacje dogmatów wiary i prawa kanonicznego. Pogłębianie tej problematyki jest ważne nie tylko z punktu widzenia badań historyczno-kulturowych, ale również z punktu widzenia relacji zachodzących między tradycją i religią, tj. uchwycenia specyficznych wartości narodowych nie tylko we współczesnej, ale i w historycznej perspektywie.

\section{Literatura}

Baranowski B., 1965, Pożegnanie z diabłem i czarownica, Łódź.

Brückner A., 1970, Stownik etymologiczny języka polskiego, Warszawa.

Getka J., 2012, Prosta mowa końca XVIII wieku. Język „Nauk Parafialnych” (Poczajów 1794). Warszawa. 
Gloger Z., 1900, Czary i Czarownice, w: Z. Gloger, Encyklopedja staropolska ilustrowana, druk P. Laskauera i W. Babickiego. Warszawa 1900, t. 1, [online], http://pl.wikisource.org/wiki/Strona:PL_Gloger-Encyklopedja_staropolska_ ilustrowana_T.1_283.jpg [25.02.2015]

Marek Melnyk, Lacińskie tradycje w Kościele greckokatolickim, Historia $i$ teraźniejszość, [online], http://grekokatolicy.pl/aktualnosci/acinskie-tradycje-wKociele-greckokatolickim..html [czerwiec 2016]

Voronau V., 2014, Szeptem, Białystok.

Зноско К., 1932, Латинизачия православного Богослужения в Униатской иеркви. Warszawa.

Чистович И., 1884, Очерк истории Западно-Русской Церкви. Санкт Петерсбург, ч. 2.

Koronczewski A., 1779, Theologia moralna dla sposobiacych sie do stanu Kapłańskiego y owszem wszystkich duchownych staranie dusz ludzkich maiacych... w swych traktatach zebrana przez... archiprezbitera kathedralnego i officjata brzeskiego, archidiakona wtodzimirskiego cz. I, II, Supraśl.

Kulczycki P., 1787, Treść Teologiczney nauki obyczainey Z Autorow Klassycznych Antoine i innych lacinskich przez rozmowy na ksztalt katechizmu dla latwiejszego uczenia się i poięcia osobom duchownym..., Poczajów.

Kulczycki P., 1792, Treść Teologiczney nauki obyczainey z autorow Klassycznych Antoine $i$ innych lacińskich przez rozmowy na ksztalt katechizmu dla latwiejszego uczenia się i poięcia osobom duchownym... Niegdyś od S.P.J.X. Kulczyckiego... wybrana, a teraz odnowiona..., Poczajów.

Kyriatt A., 1799, Theologia dogmatyczna z autorów w tey o Bogu y rzeczach boskich umieiętności dobrze zasłużonych wyjęta przez X. Ambrożego Kyriatta Z.S.B. W. Kapłana w Semin. Brzeskim na polskim dyalekcie dawana..., Wilno.

Narolski J., 1777, Teologia moralna albo do obyczaiów ściagaiaca sie przez pewnego Bazyliana Kaptana Prow. Litew. Zebrana na dwie części podzielona..., Wilno.

Narolski J., 1791, Teologia moralna albo do obyczaiów sciagaiaca się przez przez X. Z.S. Bazylego W.S.Th.D. I jej niegdyś profesora zebrana, na dwie cześci podzielona, a teraz potrzebnemi w wielu mieyscach do pierwszey czéści przydatkami od autora pomnożona..., Wilno.

Trebnik 1741, Молитвослов си есть Требник Poczajów.

Антоіне П. Г., 1776а, Богословіе нравоучителное повсемственное, честнымъ отиемъ Павломъ Гаврїиломъ Антоіне Пресвитеромъ и оучителемъ ст. Богословія, перве латинскимъ диалектомъ потонку исписанное, Многажды в ползу Парохомъ и Духовникомъ Тупомъ издаваемое, Ново монахами чина святаго Васіліа Великаго на русскій діалект преведеное и во оудобное наставитися от него хотящимї оупотребленіе, по засвидптелствованїю Богослововъ, и произволенхю Начальствующихъ Таже по Благословленїю его преосщенства Киръ Свлвестра Лубіеніецкаго Рудньикаго, Еъарха всея России, Луикаго, и Острогскаго Епископа ОрдінаС(вя)таго Станїслава Кавалера напечатаное..., Pосzајów 1776. 
Антоіне П. Г., 1776b, Краткое на краткія вопросы и отвіти способом катихісма, богословія нравоучителнаго... собраніє из книги Антоіне пространно в ней и схоластіческим художеством написаннаго во удобное всякому того поразумініе..., Pосzајów.

Антоіне П. Г., 1788, Богословіе нравоучителное из богословія Антоіне, Тоуриели и Реиффенстуель, пространно римским диалектом о таинах и иенсурах сирпчь казнех либо надзираніах иерковных написаннаго на русскій діалект вкратип по благоволению и благословению его преосвященства Кир Киприана Стецкаго екзарха всея России, Луцкаго и Острогскаго епископа преведеное, таже в ползу требующым о сих наставления типом по повелению того же изданое в святой и чудотворной обители Почаевской, Чина Святаго Василиа Великаго 1779 года, Роczajów, wyd. 6.

Богословіа нравоучителная 1751, Богословіа нравоучителная, содержащая в себп собраное вкратцп поученіе о святых тайнах, о добродптелях богословских, о заповпдех Божїх, о заповпдех иерковньх, о грпхах, о казнех и карах иерковных с приложеніем обычныя науки о догматах веры кафолическія, и лексікона славенско-полскаго..., Pосzајów.

Богословіа нравоучителная 1752, Богословіа нравоучителная, содержащая в себп Поученіе о святых тайнах, о добродптелех богословскихъ, о заповпдех Божиих и черковных, о грпхах, о казнех и карах черковньх в кратип собранное, особомъ духовньмъ, наипаче же Пресвитерам парохиалньли и до сана Іерейскаго готовяйімся благопотребное..., Lwów.

Богословіа нравоучителная 1756, Богословіа нравоучителная, содержащая в себп собраное вкратип поученіе о святьх тайнах, о добродптелях богословских, о заповпдех Божиих, о заповпдех иерковных, о грпхах, о казнех и карах иерковных с приложеніем обычныя науки о догматах веры кафолическія, и лексікона славенско-полскаго, особам духовным, наипаче пресвитерам парохиалным благопотребное, в монастире Почаевском Чина Святаго Васіліа Великаго Року от воплощения Христова 1756 типом изданая, Poczajów.

Богословіа нравоучителная 1787, Богословия нравоучителная, содержащая в себп собраное вкратип поученїе о святых тайнахъ, о добродптелехъ б[о]гословскихъ, о заповпдехъ б[о]жїиъ, о заповпдяхъ иерковныхъ, о грпхахъ, о казнехъ сиречь карахъ черковныхъ, съ приложениемъ обычныя науки о догматах веры кафолическія и некоторыхъ ведомостей особамъ духовнымъ, наипаче же пресвитеромъ парохіалнымъ благопотребное, Poczajów.

Богословіе нравоучителное 1793, Богословіє нравоучителное з богословія Антоіне, Тоуриели и Реіффенстуель пространно римским діалектом о тайнах ... на рускій діалект вкратцп ... преведеное ..., Poczajów.

Краткое сословіе науки хрістіанскія катофическому человеку многополезное и потребное..., 1759.

Краткое на краткія вопросы и отвпты способом катихісма Богословія 
о тайнах черковных и ченсурах собраніе, на ексамен готовящимся потребноє, со отсыланіем к пространному описанію тых же таин в книзі нареченной: Богословіе нравоучителное 1781, Poczajów.

Поученіе о с[вя]тих тайнах 1745, Поученіе о с[вя]тих тайнах, о добродптелех б[о]гословских, о заповпдех Б[о]жїъ, о заповпдех черковніхъ, о грпхахъ, о казнехъ и карахъ и/е]рковніх': C пріложеніем обичной наукь о догматах впры кафолической въ кратип собранное: Особом д[y]ховнӥмъ, найпаче же презвитеромъ парохӥалнӥмъ благопотребное, Uniów.

Слово къ народу кафоліческому 1765, Слово $\kappa$ народу кафолическому чрез монахов чина св. Василія Великого в провіниіи Полской званію катихистічному прилежающих в повптп Кременечком року... 1756 проповпданое, Poczajów.

Собранїе прыпадковъ 1722, Собранїе прыпадковъ краткое и дух[о]внымъ особамъ потребное импщее въ себп науку о сакраментахъ, о десати Б[ж]їих приказаняхъ о приказаняхъ иерковньхъ и о науци хрїстїанской съ вьюладомъ молитвь Отче нашъ и В[о](г)[о]родьце Дпво ильь исповпданыя Вирп православнія католичискїя... Supraśl.

Собранїе прыпадковъ 1732, Собраніє припадков краткое и духовным особам потребноє. Имущее в себп науку о сакраментах, о десяти божіих приказанях, о приказанях иерковных и о науці христіанской, с выкладом символа, или исповпданія віры православныля кафолическія, с выкладом молитвы: отче наш и богородиче дюво. Такожде науку како подобает наставляти малых или невіжов в впры православной содержащее... Uniów.

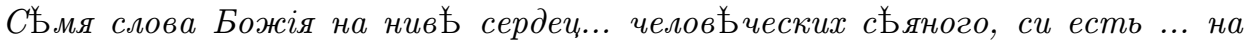
недђли... і праздники... поученія от іноков Почаєвського монастиря

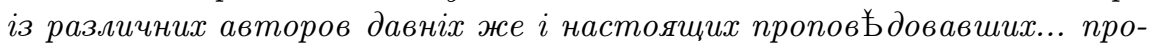
стим язиком простійшаго ради іже по всех народа сложенная, Росzаjów 1772.

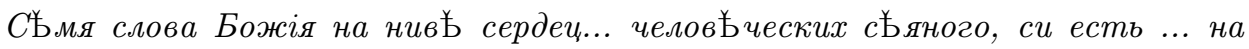
недҒли.. i праздники... поученія от іноков Почаєвського монастиря із различних авторов давніх же $i$ настоящих пропов Бेдовавших... простим язиком простійшаго ради іже по всех народа сложенная 1781.

THE CHRISTIAN WORLD AGAINST THE SLAVIC HERITAGE. FOLK BELIEFS IN BASILIAN'S MORAL THEOLOGIES (EIGHTEENTH CENTURY)

S U M M A R Y

Since the dawn of ages the mankind has been bothered with the existence problems. Therefore spells, magic and sorcerers have always been an object of interest of both secular society and the church hierarchy. The church treated them as a threat to the grounding of faith. 
Based on the decision of the Synod of Zamosc (1720) the Basilians written their moral theologies containing the teaching of the Church's standards of conduct. The moral theologies were strongly influenced by folk beliefs and imaginings. Therefore Basilian's moral theologies perfectly reflect the status of folk beliefs in the eighteenth century. Folk beliefs are not described explicitly, but descriptions of sins against Commandments give their image.

The purpose of this article is to capture the state of folk beliefs on the one hand, and on the other hand - the dogmas of moral theology in the eighteenth century. Both of these systems have been modified, but even in these days still penetrate each other, especially in folk culture. 